\title{
EVALUATION ON THE EFFECTS OF CULTURE MEDIUM ON REGENERATION OF OIL PALM PLANTLETS FROM IMMATURE EMBRYOS (IE)
}

\author{
WAN NUR SYUHADA, W S*; RASID, O A* and PARVEEZ, G K A*
}

\begin{abstract}
Oil palm (Elaeis guineensis) tissue culture is slow, inefficient and genotype dependent. Therefore, efforts to improve the regeneration system are essential and thereby on-going. Immature embryos (IE) have been reported to be more responsive to in vitro culture as compared to other explant types. The objective of this study is to evaluate the most efficient culture media for the regeneration of whole plants from IE. IE were cultured on three media, namely N6, MY3 and MS +Y3. Initial observation showed that calli were induced as early as two weeks after culture. They started to produce friable calli around three to four months later. IE were shown to respond differently to the tested culture media. This initial result will be useful to identify the most responsive culture media for IE as explant.
\end{abstract}

Keywords: immature embryos, oil palm, tissue culture, media.

Date received: 7 July 2015; Sent for revision: 9 July 2015; Received in final form: 18 April 2016; Accepted: 21 April 2016.

\section{INTRODUCTION}

Oil palm (Elaeis guineensis) is a monocotyledonous species with a single growing apex, the plant cannot be multiplied vegetatively. Therefore, the only alternative for multiplication of oil palm elite genotype is through tissue culture approach (Parveez et al., 2012). However, tissue culture of oil palm is hampered by the difficulty to produce an efficient, reliable and rapid regeneration system (Kushairi et al., 2010). Furthermore, there is also a challenge to eliminate or minimise somaclonal variation (Corley and Tinker, 2003). Somatic embryogenesis or organogenesis in oil palm is a complicated process that requires consideration a number of factors for it to be successful. Two of the key elements for the production of somatic embryogenesis in oil palm are the choice of explants and the selection of culture medium.

Malaysian Palm Oil Board, 6 Persiaran Institusi, Bandar Baru Bangi, 43000 Kajang, Selangor, Malaysia. E-mail: parveez@mpob.gov.my
To date, there are many reports on oil palm regeneration using various explants such as young leaf (Schwendiman et al., 1988), mature embryos (Teixera et al., 1993), immature embryo (IE) (Abdullah et al., 2005), root and oil palm inflorescence (Guedes et al., 2011), and protoplast (Masani et al., 2013). Generally, for many plant species, embryo is suggested to be the choice of explant as it has the highest embryogenic potential; and this is followed by hypocotyl, petiole, leaf lamina and root (Neumann, 2000). For oil palm, IE has the advantage over other explants because of its abundance. A total of 300 to 500 IE could be isolated from a single fruit bunch which could be easily transported for a long distance without much effect on its regenerability (Teixera et al., 1993; Abdullah et al., 2005). IE could respond well in culture because it has cells that possess embryogenic destiny. In contrast, cells in differentiated tissues must erase the existing developmental programme by undergoing numerous changes into embryonic state (Elhiti and Stasolla, 2011). Therefore, younger tissues such as the IE are the preferred choice as they have better potential and competency since the explant requires low inductive signal compared to others (Elhiti and Stasolla, 2011). 
The IE can also be used as target tissues for transformation studies to produce genetically engineered oil palm (Abdullah et al., 2005). The main objective of oil palm genetic engineering programme is to maintain the oil palm industry's sustainability in facing various challenges. Among the targets of oil palm genetic engineering are to increase the content of oleic acid, stearic acid, palmitoleic acid, ricinoleic acid, lycopene content and synthesising biodegradable plastics (Parveez et al., 2015; Rasid et al., 2014). The potential of using the IE as target tissues for oil palm transformation has not been fully explored and examined. Abdullah et al. (2005) reported that putative transgenic oil palm plantlets were regenerated from IE. However, the report was not definitive as it did not provide molecular evidence of the integration of the transgene. Effort to transform oil palm IE using the green fluorescence protein $(g f p)$ gene was also initiated, involving optimising the transformation conditions, genes constructs and selection agents, however, regeneration of transgenic oil palm plants expressing $g f p$ gene has not been reported to date (Na'imatulapidah and Parveez, 2007; Parveez and Na'imatulapidah, 2008; Parveez et al., 2007). Recently, Bhore and Shah (2012) demonstrated the efforts to transform IE of Elaeis oleifera (another species of oil palm which is not planted commercially).

The IE of oil palm are derived from a cross pollination between two separate parents and therefore their genetic backgrounds are not uniform (Abdullah et al., 2005). As oil palm has a very long life span of 25 to 30 years, the planting of seedlings derived from known and selected parents are critical. The IE are being non-uniform, are therefore makes IE as a not preferable choice for oil palm tissue culturists. For commercial tissue culture process, IE have never been used due to the above drawback. Thus, the best alternative for getting maximum benefit is by using IE obtained from controlled pollination of selected commercial parents.

The composition of medium used to sustain embryos is a key to successful culture. There are three main base medium that has been used to culture zygotic embryo of oil palm which are MS (Murashige and Skoogs, 1962), N6 (Chu et al., 1975) and Y3 (Eeuwens, 1976). Until now there are nonstandard medium to culture the zygotic oil palm embryo. MS medium is classified as a high salt medium in comparison to many other formulations, with high levels of nitrogen, potassium and some of the micronutrients, particularly boron and manganese (Cohen, 1995). However, Eeuwens (1976) reported that Y3 medium was better than MS medium for calli initiation in coconut due to mineral deficiencies in macro elements such as nitrogen (ammonium), potassium and in micro elements such as iron and molybdenum. These basic media have been modified, namely MY3 (Muniran et al.,
2008), MS+Y3 (Parveez, 2010) and N6 (Thuzar et al., 2011), which have been reported to successfully generate complete plantlets from IE. However, there is no optimised medium to culture the oil palm IE. Therefore, in this study, the IE derived from different genetic backgrounds (different parents) were cultured on MY3, MS+Y3 and N6 media and the efficiency of callus induction and plant regeneration were evaluated.

\section{MATERIALS AND METHODS}

\section{Plant Materials}

Immature oil palm fruit bunches were obtained from MPOB Research Station, Kluang, Johor, Malaysia. Loose fruits were sterilised in $10 \%$ sodium hypochlorite for $10 \mathrm{~min}$. Fruits were thoroughly washed in sterile water seven times. The fruits were then soaked in $70 \%$ ethanol for 15 min and dried in laminar flow cabinet. IEs were isolated from the fruits (Figure 1) and cultured on the media.

\section{Induction of Calli}

Experiments were set up to investigate the effects of the following three media; (1) MS+Y3 (Parveez, 2010), (2) N6 (Thuzar et al., 2011) and (3) MY3 (Muniran et al., 2008), on callus induction from IE (Table 1). Each treatment consisted of 50 embryos (10 petri dishes; five embryos per petri dish) and performed in three replicates. The cultures were incubated at $28^{\circ} \mathrm{C} \pm 2^{\circ} \mathrm{C}$ under cool-white fluorescent lamp $\left(50-60 \mu \mathrm{mol} \mathrm{m}^{-2} \mathrm{~s}^{-1}\right)$ for $16 \mathrm{hr}$ photoperiod. Subculture was performed on monthly basis and the number of calli and embryogenic calli induced were scored and recorded for each treatment.

\section{Callus Suspension}

Suspension cultures were initiated by shaking $1 \mathrm{~g}$ of friable callus at $150 \mathrm{rpm}$ in the dark at $28^{\circ} \mathrm{C}$ in a $100 \mathrm{ml}$ Erlenmeyer flask containing $20 \mathrm{ml}$ of suspension liquid medium (MS macro, MS micro, Y3 vitamins, $0.1 \mathrm{~g}$ litre $^{-1}$ myo-inositol, $0.1 \mathrm{~g}^{-1}$ litre $^{-1}$ L-glutamine, $0.1 \mathrm{~g}$ litre $^{-1} \mathrm{~L}$-asparagine, $25 \mu \mathrm{M}$ 2,4-D and $30 \mathrm{~g} \mathrm{litre}^{-1}$ sucrose). After one month, calli were transferred into $20 \mathrm{ml}$ of fresh suspension medium.

\section{Development, Maturation and Germination of Somatic Embryos}

Embryogenic calli were transferred onto EC medium (MS macro, MS micro, Y3 vitamins, 0.1 g litre $^{-1}$ myo-inositol, $0.1 \mathrm{~g}^{\text {litre }}{ }^{-1}$ L-glutamine, $0.1 \mathrm{~g}$ litre $^{-1} \mathrm{~L}$ - asparagine, $0.1 \mu \mathrm{M}$ NAA and $30 \mathrm{~g}$ litre $^{-1}$ sucrose) for maturation. Subcultures were performed monthly onto fresh medium for three to six passages until polyembryoids were initiated. 


\begin{tabular}{|c|c|c|c|}
\hline \multirow[b]{2}{*}{ Chemicals } & \multicolumn{3}{|c|}{ Concentration mg litre ${ }^{-1}$} \\
\hline & MY3 & N6 & MS + Y3 \\
\hline \multicolumn{4}{|l|}{ Macro-nutrients } \\
\hline $\mathrm{NH}_{4} \mathrm{Cl}$ & 535 & - & - \\
\hline $\mathrm{KNO}_{3}$ & 2020 & 3134 & 1900 \\
\hline $\mathrm{MgSO}_{4} \cdot 7 \mathrm{H}_{2} \mathrm{O}$ & 247 & 185 & 370 \\
\hline $\mathrm{CaCl}_{2} \cdot 2 \mathrm{H}_{2} \mathrm{O}$ & 294 & 166 & 440 \\
\hline $\mathrm{KCl}$ & 1492 & - & - \\
\hline $\mathrm{NaH}_{2} \mathrm{PO}_{4} \cdot \mathrm{H}_{2} \mathrm{O}$ & 312 & - & - \\
\hline$\left(\mathrm{NH}_{4}\right)_{2} \mathrm{SO}_{4}$ & - & 231.5 & - \\
\hline $\mathrm{KH} 2 \mathrm{PO} 4$ & - & 540 & 170 \\
\hline $\mathrm{NH}_{4} \mathrm{NO}_{3}$ & - & - & 1650 \\
\hline \multicolumn{4}{|l|}{ Micro-nutrients } \\
\hline KI & 8.3 & 0.8 & 8.3 \\
\hline $\mathrm{H}_{3} \mathrm{BO}_{3}$ & 3.1 & 6.2 & 3.1 \\
\hline $\mathrm{MnSO}_{4} \cdot 4 \mathrm{H}_{2} \mathrm{O}$ & 11.2 & 16 & 11.2 \\
\hline $\mathrm{ZnSO}_{4} .7 \mathrm{H}_{2} \mathrm{O}$ & 7.2 & 8.6 & 7.2 \\
\hline $\mathrm{NaMO}_{4} \cdot 2 \mathrm{H}_{2} \mathrm{O}$ & 0.24 & 0.24 & 0.24 \\
\hline $\mathrm{CuSO}_{4} \cdot 6 \mathrm{H}_{2} \mathrm{O}$ & 0.16 & 0.05 & 0.25 \\
\hline $\mathrm{CoCl}_{2} \cdot 6 \mathrm{H}_{2} \mathrm{O}$ & 0.24 & 0.05 & 0.24 \\
\hline $\mathrm{NiCl}_{2} \cdot 6 \mathrm{H}_{2} \mathrm{O}$ & 0.024 & - & 0.024 \\
\hline \multicolumn{4}{|l|}{ Iron sources } \\
\hline $\mathrm{Na}_{2}$ EDTA & 37.3 & 37.2 & - \\
\hline $\mathrm{FeSO}_{4} \cdot 7 \mathrm{H}_{2} \mathrm{O}$ & 27.8 & 27.8 & - \\
\hline NaFeEDTA & - & - & 37.5 \\
\hline \multicolumn{4}{|l|}{ Vitamins } \\
\hline Myo-Inositol & 100 & 100 & 100 \\
\hline Pyridoxine- $\mathrm{HCl}$ & 0.05 & 2.5 & 1 \\
\hline Thiamine- $\mathrm{HCl}$ & 0.5 & 2.5 & 1 \\
\hline Glycine & 2 & 2.5 & - \\
\hline Nicotinic acid & 1 & 2.5 & - \\
\hline \multicolumn{4}{|l|}{ Amino acids } \\
\hline L-Glutamine & 100 & - & 100 \\
\hline L-Arginine & 100 & - & - \\
\hline L-Asparagine & 100 & - & - \\
\hline $2,4-\mathrm{D}$ & 2.5 & 2 & 2.2 \\
\hline Sucrose & $45{\text { g } \text { litre }^{-1}}$ & 30 g litre $^{-1}$ & $30 \mathrm{~g}$ litre $^{-1}$ \\
\hline Agar (phytagel) & $2.5 \mathrm{~g} \mathrm{litre}^{-1}$ & 3 g litre $^{-1}$ & $2.5 \mathrm{~g}_{\text {litre }} \mathrm{-}^{-1}$ \\
\hline $\mathrm{pH}$ & 6 & 5.8 & 5.7 \\
\hline
\end{tabular}

\section{RESULTS AND DISCUSSIONS}

Generally, there are three steps that lead to the production of plantlets via somatic embryogenesis, namely (1) induction and maintenance of embryogenic state, (2) development and maturation of somatic embryos, and (3) regeneration of plantlets from somatic embryos (Thuzar et al., 2011). In the somatic embryogenic systems, there are two types of induction process: direct or indirect. In direct somatic embryogenesis, the embryos develop to plantlets without going through callusing phase, whereas in the indirect somatic embryogenesis, the high division of the cells is required through a callusing phase (Neumann, 2000). IE were

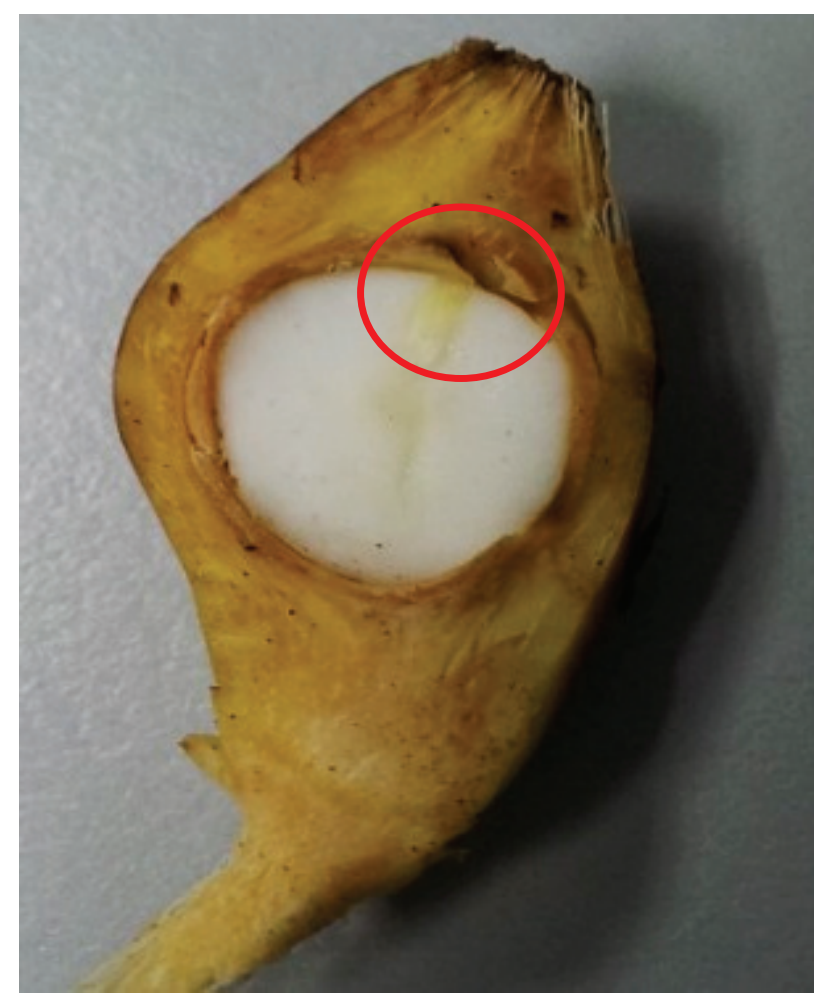

Figure 1. The location of embryo (red circle) in halved fruit surrounded with kernel.

isolated from immature fruits before being cultured separately on the three media. It was observed that the IE started to swell after one week on the three culture media.

After four weeks, the IE started to show the formation of yellowish compact calli. The types and appearance of calli produced from the immature embryos on the three media are shown in Figure 2. The primary calli formed on MS+Y3 medium were shown to be comparatively larger, yellowish in colour and compact in nature (Figure 2a). Meanwhile, calli produced on MY3 medium were mainly smaller in size with dark brown to blackish in colour (Figure 2b). For N6 medium, calli formed a mixture of yellowish and compact in nature with majority of them are smaller in size and appeared brownish (Figure 2c).

After 12-17 weeks on the three callus induction media, the compact calli (Figure 3a) started to produce friable calli (Figure $3 b$ ). The friable calli were yellowish in colour and looked like fish eggs. They were easily detached from the primary calli. However, this type of calli was typically formed at a low frequency compared to compact calli. The friable calli were later isolated and transferred into suspension liquid medium (Figure 3c) for multiplication. After eight months, the calli were transferred onto EC medium for the differentiation and maturation phases (Figure $3 d$ ). After around 17 weeks on the EC medium, the friable calli started to develop into whitish somatic embryos which then developed through bipolar and globular stages 

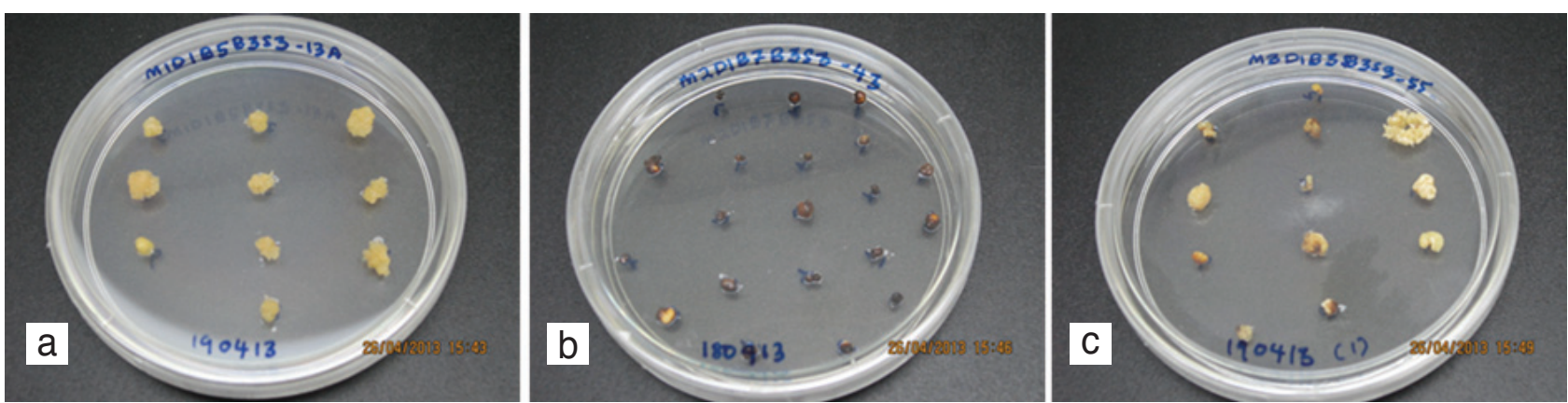

Figure 2. Callus development from immature embryos (IE) cultured on three different culture media. a) Calli produced on MS+Y3 medium; b) calli produced on MY3 medium and c) calli produced on N6 medium.

(Figure 3e). These somatic embryos are currently in shoot development stage (Figure 3f).

The highest frequency of friable callus formation was observed from IE cultured on MS+Y3 medium were 41.25 followed by N6 and MY3 media were 9.25 and 18.5 , respectively (Figure 4). It was observed that IE successfully produced friable calli when cultured on MS+Y3 medium. In contrast, not all IE produced friable calli when cultured on MY3 and N6 media. The friable calli have been reported to be the best materials for mass production and genetic transformation ( $\mathrm{Li}$ and Qu, 2010; Frame et al., 2000). In this preliminary work, MS+Y3 medium was shown to be the most efficient medium for callus induction from oil palm IE. The MS+Y3 medium consists of macro-elements from MS medium and micro-elements of Y3 medium. Similar observation was reported by Eeuween (1976) in their study in coconut palm. It was shown that the medium which contained MS macro and Y3 micro, was superior and met the requirement for the culture of tissue from mature coconut palms (Cocos nucifera). The MS+Y3 medium contains higher concentration of calcium sources as compared to N6 and MY3 media (Table 1). In plant, calcium regulates calcium signalling and act as a good stimulator for somatic embryogenesis (Ghasemi et al., 2009). In addition, MS+Y3 contains ammonium nitrate which has been suggested to affect somatic embryogenesis by modifying the explants' sensitivity to auxin (Kothari et al., 2004). The result showed that the nutrient composition of MS+Y3 is more suitable for cell growth and cell differentiation of callus than nutrient composition of MY3 and N6 media.

\section{CONCLUSION}

The present preliminary study demonstrated the effect of three different culture media on callus formation of IE derived from four different genetic backgrounds. Initial data demonstrated that the MS

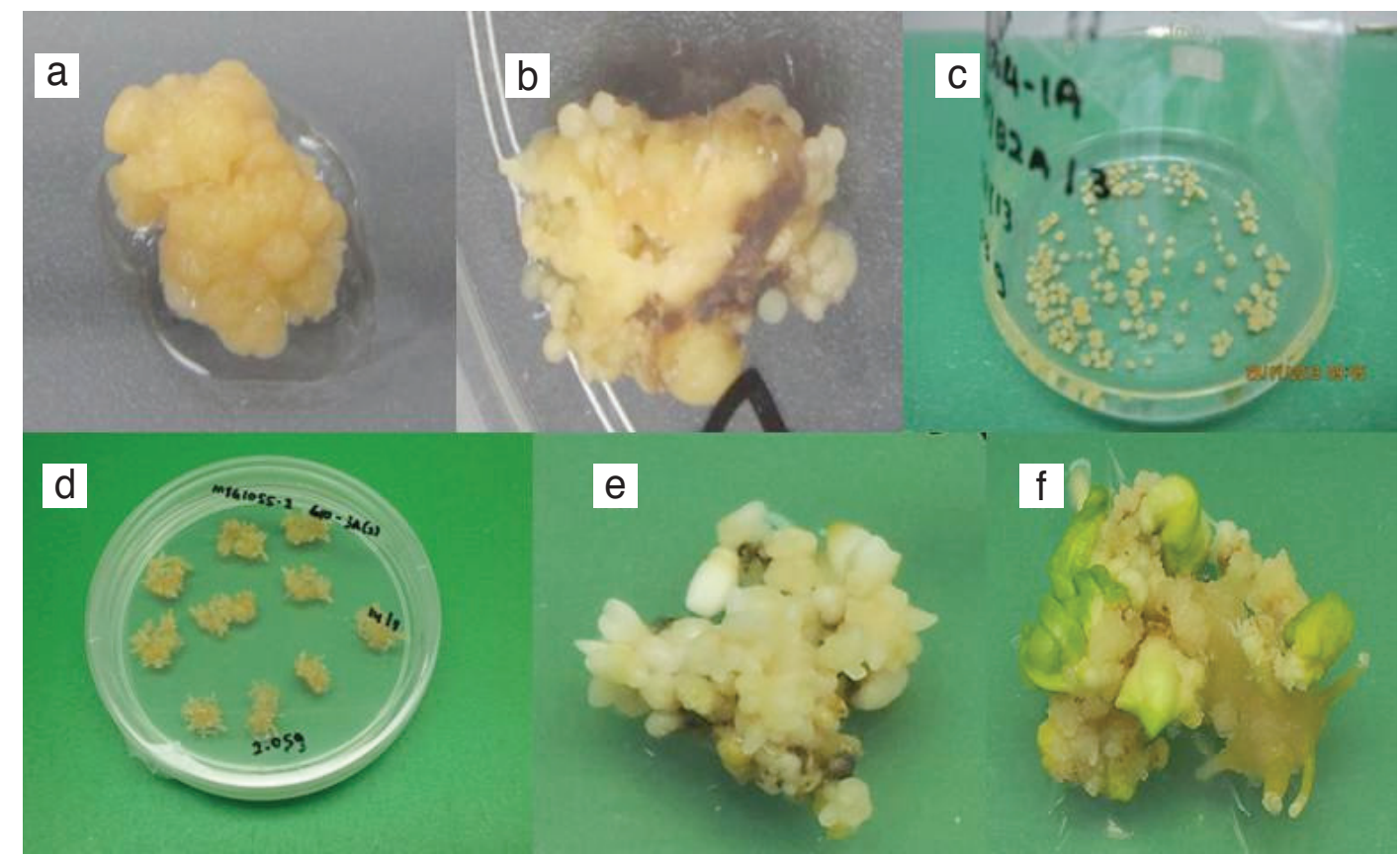

Figure 3. Callus development from immature embryo (IE) explants. a) Compact calli; b) friable calli; c) friable calli in suspension culture; d) friable calli maturation on EC medium; e) somatic embryos and f) somatic embryos developing into shoot. 


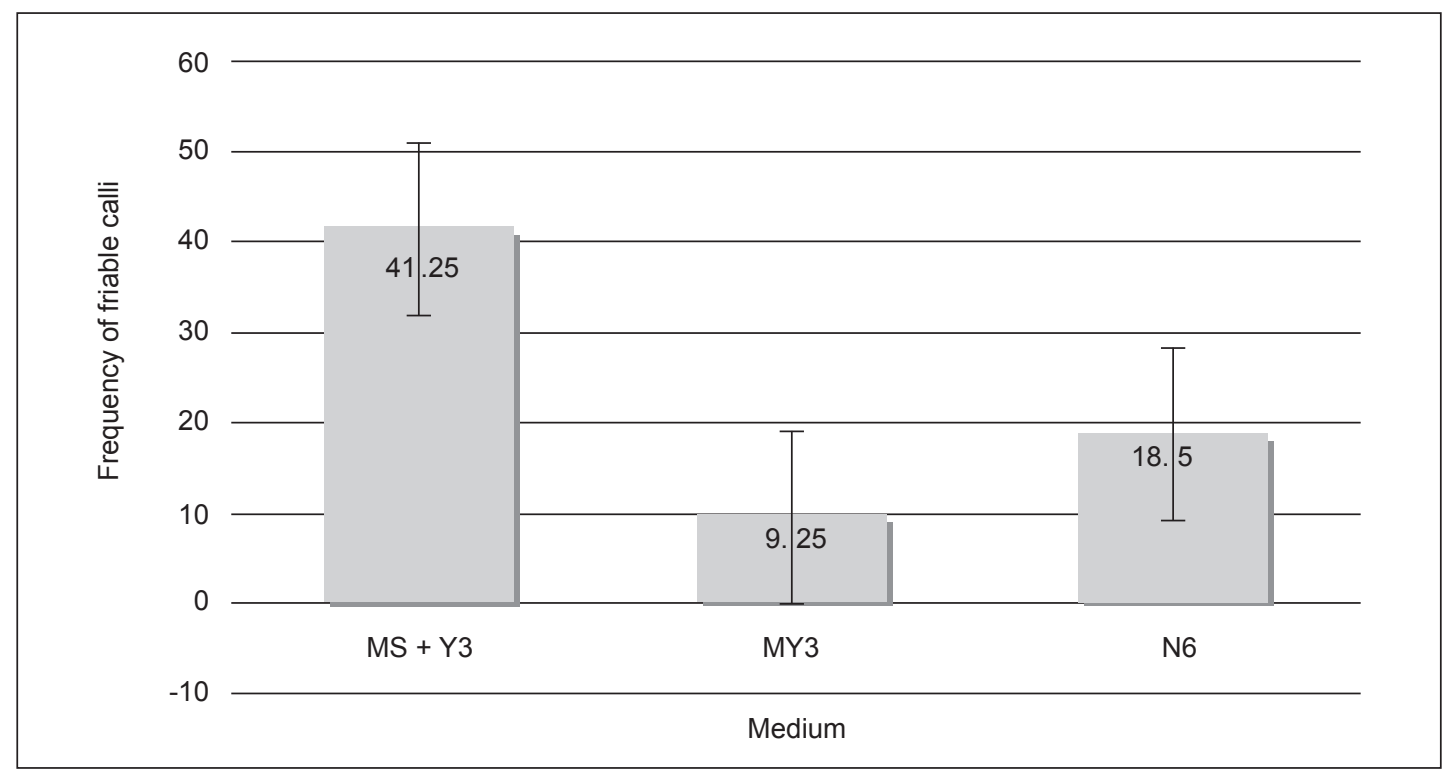

Figure 4. The frequency of friable calli that were produced from primary calli of oil palm by three media; MS + Y3, MY3 and N6.

+ Y3 medium is the most suitable medium for oil palm IE callus induction. The results clearly suggest that further studies to look at the effects of this medium on IE derived from a wide range of genetic backgrounds is needed. The outcome of such work will have a clear advantage in identifying the best culture media that will have the highest rate of regeneration in a genotype independent manner.

\section{ACKNOWLEDGEMENT}

The authors wish to thank the Director-General of $\mathrm{MPOB}$ for permission to publish this article. We also would like to thank Dr Mohd Din Amiruddin, Marhalil Marjuni from the Breeding and Quantitative Genetics Group for performing the crosses and supplying the oil palm immature bunches. We are deeply grateful to Dr Ahmad Tarmizi Hashim, Zamzuri Ishak and the staff of Clonal Propagation Group for their advice and technical assistance. We also thank the staff of Transgenic Technology Laboratory for their technical assistance. Finally, special thanks to Dr Abdul Masani Mat Yunus and Nor Hanin Ayub for critically reviewing the manuscript.

\section{REFERENCES}

ABDULLAH, R; ZAINAL, A; HENG, W Y; LI, L C; BENG, Y C; PHING, L M; SIRAJUDDIN, S A; PING, W Y S; JOSEPH, J L; JUSOH, S A; MUAD, M R and HUEY, Y L (2005). Immature embryo: a useful tool for oil palm (Elaeis guineensis Jacq.) genetic transformation studies. Electron J. Biotechnol., 8: 2434.
BHORE, S J and SHAH, F H (2012). Genetic transformation of the American oil palm (Elaeis oleifera) immature zygotic embryos with antisense palmitoyl-acyl carrier protein thioesterase (PATE) gene. World Appl. Sci. J., 16 (3): 362-369.

CHU, C C; WANG, C C; SUN C S; HSU C; YIN, K C; CHU, C Y and BI, F Y (1975). Establishment of an efficient medium for anther culture of rice through comparative experiments on the nitrogen sources. Sci Sin., 18: 659-668.

CORLEY, R H V and TINKER, P B (2003). The Oil Palm. $4^{\text {th }}$ Edition, Blackwell Publishing Company, UK. p. 562.

EEUWENS, C J (1976). Mineral requirements for growth and callus initiation of tissue explants excised from mature coconut palms (Cocos nucifera) and cultured in vitro. Physiol. Plant, 36 (1): 23-28.

ELHITI, M and STASOLLA, C (2011). Ectopic expression of the Brassica shoot meristemless attenuates the deleterious effects of the auxin transport inhibitor TIBA on somatic embryo and morphology. Plant Sci., 180: 383-390.

FRAME, B R; ZHANG, H; COCCIOLONE, S M; SIDORENKO, L V; DIETRICH, C R and PEGG, $S$ E (2000). Production of transgenic maize from bombarded type II callus: effect of gold particle size and callus morphology on transformation efficiency. In vitro Cell. Dev. Biol. - Plant, 36: 21 -29.

GHASEMI, Y; MASHAYEKHI, K; GHASEMNEZHAD, A and MOVAHHEDI, S A (2009). The effects of calcium and magnesium 
on carrot (Dacus carota cv. Nants) petiole somatic embryogenesis. International J. Plant Production, 3 (4): 67-70.

KOTHARI, S L; AGARWAL, K and KUMAR, S. (2004). Inorganic nutrient manipulation for highly improved in vitro plant regeneration in finger milletEleusine coracana (L.) gaertn. In vitro Cell and Dev. Bio. - Plant, 40: 515-519.

KRZYŻANOWKA,D;GÓRECKAKand KISZCZAK, W and KOWALSKA, U (2006). The effect of genotype and medium on plant regeneration from androgenic embryos. J. Fruit Ornam. Plant Res., 14: 121-127.

KUSHAIRI, A; TARMIZI, A H; ZAMZURI, I; ONGABDULLAH, M; SAMSUL KAMAL, R; OOI, S E and RAJANAIDU, N (2010). Production, performance and advances in oil palm tissue culture. Paper presented at the International Seminar on Advances in Oil Palm Tissue Culture, Yogyakarta, Indonesia on 29 May 2010.

LI, R and QU, R (2010). High throughput Agrobacterium-mediated switchgrass transformation. Biomass and Bioenergy. p. 1-9.

MARIA, M and HEIDE, F K (2002). Auxin and sugar effects on callus induction and plant regeneration frequencies from mature embryos of wheat (Triticum aestivum L). In vitro Cell. Dev. Biol. - Plant, 38: 39-45.

MASANI, A M Y; NOLL, G; PARVEEZ, G K A; SAMBATHAMURTHI, R and PRÜFER, D (2013). Regeneration of viable oil palm plants from protoplasts by optimizing media components, growth regulators and cultivation procedures. Plant Sci., 210: 118-127.

MUNIRAN, F; BHORE, S J and SHAH, F H (2008). Micropropagation of Elaeis guineensis Jacq. 'Dura': comparison of three basal media for efficient regeneration. Ind. J. Exp. Bio., 46: 79-82.

MURASHIGE, T and SKOOGS, F (1962). A revised medium for rapid growth and bioassays with tobacco tissue cultures. Physiol Plant, 15: 473-497.

NEUMANN, H K (2000). Some studies on somatic embryogenesis, a tool in plant biotechnology. Lecture at the $87^{\text {th }}$ Indian Science Congress, Pune, India.

NA'IMATULAPIDAH, A $\mathrm{M}$ and PARVEEZ, G K A (2007). Evaluation of green fluorescence protein (GFP) as a selectable marker for oil palm transformation via transient expression. Asia Pacific J. Molecular Biology and Biotechnology, 15(1): 1-8.

PARVEEZ, G K A; RASID, O A; MASANI, M Y A and SAMBANTHAMURTHI, R (2015). Biotechnology of oil palm: strategies towards manipulation of lipid content and composition. Plant Cell Reports, 34: 533543 .

PARVEEZ, G K A; RASID, O A; TARMIZI, A H; ZAMZURI, I; SAMSUL, $\mathrm{K} R$ and SAMBANTHAMURTHI, R (2012). Tissue culture and genetic engineering of oil palm. Oil Palm: Production, Processing, Characterization'and Uses (OiMing, L; Chin-Ping, T and Casimir, C A eds.). AOCS Press:Urbana. p. 87-135.

PARVEEZ, G K A and NA'IMATULAPIDAH, A $M$ (2008). Factors affecting green fluorescence protein (GFP) gene expression in oil palm after microprojectile bombardment mediated transformation. J. Oil Palm Res. Vol. 20: 495-507.

PARVEEZ, G K A; NA'IMATULAPIDAH, A M; ALIZAH, Z and RASID, O A (2007). Determination of minimal inhibitory concentration of selection agents for selecting transformed immature embryos of oil palm. Asia Pac. J Mol. Bio. Biotech., 15(3): 133146.

PARVEEZ, G K A (2010). Method and compositions for the production of transgenic plants. US patent 7,807,866 B2.

RASID, O A; WAN NUR SYUHADA, W S; NOR HANIN, A; SINGH R, C L and PARVEEZ, G K A (2014). Molecular cloning and regulation of oil palm (E. guineensis Jacq.) phyteone desaturase in developing mesocarp tissues. J. Oil Palm Res. Vol. 26: 37-46.

SCHWENDIMAN, J; PANNETIER, $\mathrm{C}$ and MICHAUX-FERRIÈRE, N (1988). Histology of somatic embryogenesis during leaf explants of the oil palm (Elaeis guineensis Jacq). Ann. Bot., 62: 43-52.

TEIXERA, J B; SONDAHLL, M R and KIRBY, E G (1993). Somatic embryogenesis from immature immature embryos of oil palm. Plant Cell Tiss. Org. Cul., 34: 227-233.

THUZAR, M; VANAVICHIT, A; TRAGOONRUNG, $S$ and JANTASURIYARAT, C (2011). Efficient and rapid plant regeneration of oil palm immature embryos cv. 'Tenera' through somatic embryogenesis. Acta Physiol. Plant., 33: 123-128. 